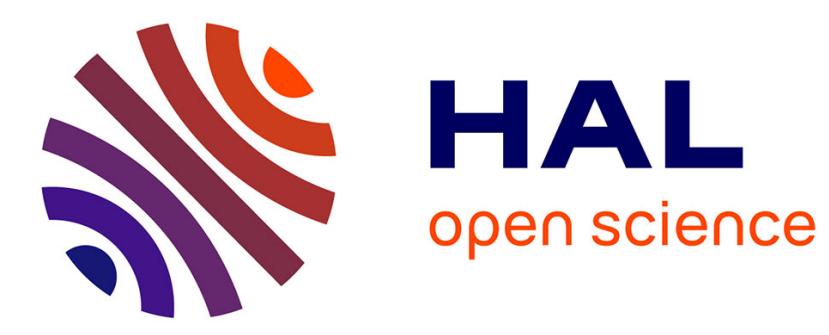

\title{
Emergence of embryo shape during cleavage divisions
}

\author{
Alex Mcdougall, Janet Chenevert, Benoît Godard, Rémi Dumollard
}

\section{To cite this version:}

Alex Mcdougall, Janet Chenevert, Benoît Godard, Rémi Dumollard. Emergence of embryo shape during cleavage divisions. Evo-Devo: Non-model Species in Cell and Developmental Biology, 2019. hal-02362892

\section{HAL Id: hal-02362892 \\ https://hal.science/hal-02362892}

Submitted on 14 Nov 2019

HAL is a multi-disciplinary open access archive for the deposit and dissemination of scientific research documents, whether they are published or not. The documents may come from teaching and research institutions in France or abroad, or from public or private research centers.
L'archive ouverte pluridisciplinaire HAL, est destinée au dépôt et à la diffusion de documents scientifiques de niveau recherche, publiés ou non, émanant des établissements d'enseignement et de recherche français ou étrangers, des laboratoires publics ou privés. 


\title{
Emergence of embryo shape during cleavage divisions
}

\author{
Alex McDougall ${ }^{1}$, Janet Chenevert ${ }^{1}$, Benoit G. Godard ${ }^{2}$ and Remi Dumollard ${ }^{1}$ \\ 1. Sorbonne Université, CNRS, Laboratoire de Biologie du Développement de Villefranche-sur-mer (LBDV), \\ UMR7009, 181 chemin du Lazaret, 06230 Villefranche-sur-Mer, France
}

2. Institute of Science and Technology Austria, 3400 Klosterneuburg, Austria

\begin{abstract}
Cells are arranged into species-specific patterns during early embryogenesis. Such cell division patterns are important since they often reflect the distribution of localized cortical factors from eggs/fertilized eggs to specific cells as well as the emergence of organismal form. However, it has proven difficult to reveal the mechanisms that underlie the emergence of cell positioning patterns that underlie embryonic shape, likely because a system-level approach is required that integrates cell biological, genetic, developmental and mechanical parameters. The choice of organism to address such questions is also important. Because ascidians display the most extreme form of invariant cleavage pattern amongst the metazoans, we have been analyzing the cell biological mechanisms that underpin three aspects of cell division (unequal cell division (UCD), oriented cell division (OCD), and asynchronous cell cycles) which affect the overall shape of the blastula-stage ascidian embryo composed of 64 cells. In ascidians, UCD creates two small cells at the 16-cell stage that in turn undergo two further successive rounds of UCD. Starting at the 16-cell stage, the cell cycle becomes asynchronous whereby the vegetal half divides before the animal half, thus creating $24,32,44$ then 64 -cell stages. Perturbing either UCD or the alternate cell division rhythm perturbs cell position. By analyzing cell shape, we discovered that cell shape propagates, via cell-cell contact, throughout the embryo following UCD and alternate/asynchronous cell division to create the ascidianspecific invariant cleavage pattern via OCD in the longest length of the apical surface of blastomeres.
\end{abstract}


Keywords Cell/embryo shape, UCD, OCD, asynchronous, apicobasal polarity, ascidian

Short title : Emergence of embryo shape

\section{INTRODUCTION}

Although we have acquired a great deal of knowledge about how genes control cell fate and axial patterning during embryonic development (Wieschaus and Nüsslein-Volhard, 2016), less progress has been made in understanding how the shape of the early embryo is generated. Even though embryo shape is species-specific and thus encoded in the DNA, understanding the phenomenon of how shape emerges during embryonic development is complex and requires going beyond the role of one or many gene products, not least because cell and embryo shape are modulated at a higher level of organization and will require a systems-level or cross-disciplinary level approach. In embryos cells can be different sizes, some cells can divide before others, while other groups of cells can divide in oriented ways during which time the cells remain adherent in the embryo. The interplay between all these factors influences the shape of the embryo. Moreover, at the cellular level apicobasal polarity becomes manifest following cell division, while many maternal RNAs, protein products, granules, and organelles that are localized to specific regions of the oocyte and fertilized egg are often distributed to specific cells during early cleavage divisions, and some of these factors can in turn influence spindle position (Sardet et al., 1994; Weitzel et al., 2004).

When considering the regulation of cell and embryo shape it should be borne in mind that DNA is subject to evolutionary change while the physical forces acting upon cells that constitute embryos have remained unchanged. e.g. cell adhesion, surface tension (for embryos, effective surface tension, manifested as an elastic property at the plasma-membrane/cortex water interface leading to a minimization of surface area) and the viscoelastic properties (for embryos, the cytoplasm including the cortex: a material that exhibits both viscous and elastic characteristics when deformed) give shape to cells, embryos and tissues and thus 
have to be taken into account (Heisenberg and Bellaïche, 2013; Winklbauer, 2015). Several proteins that regulate cell division orientation, cell shape and cell adhesion have been used in manners that create different sizes and arrangements of cells in embryos during the evolution of the extant animal phyla, and these proteins can be considered molecular toolkits that are used in sometimes subtly different ways, creating the myriad array of embryonic and larval forms. These include many proteins (and indeed organelles) that organize the positioning of the mitotic spindle, proteins that influence cell cycle duration, as well as proteins involved in generating cell shape such as cell adhesion proteins and the actomyosin cortex and its regulators.

Another important consideration is what organism to choose to answer the biological question that is being posed. It is an old concept in biology that "the fortunate choice of animal often suffices to resolve general questions of the greatest importance": Claude Bernard (1865). This concept (plus the translation of Bernard's original phrase) is discussed in Cook et al., (2016), where the idea of model organisms is covered in great detail. In addition, by using the magnifying glass of EvoDevo or comparative embryology, interesting conserved (and non-conserved) features are beginning to emerge by studying a wide array of invertebrates. However, the progress of biology has greatly benefited from studying model organisms, those organisms that received intense focus creating genetic, genomic/transcriptomic and molecular tools to dissect the principles and identify molecules that control some aspects of embryonic development (Gehring, 1996; Wieschaus and Nüsslein-Volhard, 2014, 2014). These organisms include representatives of the invertebrates: the fly Drosophila and the worm C. elegans (members of the Ecdysozoa), and the vertebrates: Xenopus, zebrafish, chicken and mouse. Notwithstanding the progress made with canonical model organisms, embryonic development has also been studied in marine invertebrate organisms for more than a century, including members of the cnidarians (eumetazoans), the super phylum lophotrochozoa (mollusks, annelids and many more), echinoderms such as the sea urchin (a deuterostome), invertebrate chordates such as amphioxus (a cephalochordate), and the ascidian (a 
tunicate). Now, with the emergence of techniques for gene editing such as CRISPR/Cas9 coupled with the availability of transcriptomic and genomic data, techniques and genomic resources that were once restricted to the canonical model organisms are now accessible for many diverse marine invertebrate species (Cook et al., 2016). A brief example of some genomic and transcriptomic resources available is included below (not an exhaustive list):

jellyfish, sea urchin, amphioxus : http://marimba.obs-vlfr.fr/downloads/,

echinoderms: $\underline{\text { http://www.echinobase.org/Echinobase/, }}$

amphioxus: https://genome.jgi.doe.gov/Brafl1/Brafl1.home.html,

and ascidians : https://www.aniseed.cnrs.fr/ or http://ghost.zool.kyoto-u.ac.jp/cgi-bin/gb2/gbrowse/kh/

Finally, a number of computational models have been provided that explain cell positioning mechanisms in different embryos, and common to these models are that cell adhesion and cortical sites influence spindle position. In nematodes, both the egg shell and attractive forces provided by cell adhesion can explain cellular position of different species at the 4-cell stage where cells are aligned to form pyramid, diamond, T-shapes or linear shapes (Yamamoto and Kimura, 2017). A computational model of spiral cleavage depends on a set of rules including cell division polarized along the animal-vegetal axis, Sachs' rule (see definition later), cortical rotation and cell adhesion (Brun-Usan et al., 2017). A mathematical model of the first four cleavage divisions for sea urchin embryos is based on cortical sites (Akiyama et al., 2010). In the ascidian, an apical cell shape computational model that integrates unequal cell division (UCD), asynchronous cell cycles and apical cell shape can explain spindle positioning up to 64-cell stage (Dumollard et al., 2017). 


\subsection{The importance of cell position during early embryogenesis}

The position of cells during the earliest stages of embryogenesis is vitally important for subsequent events in many embryos. In some species of mollusk, the cleavage direction at the 4 to 8 -cell stage has been shown to influence the spiral direction of the adult shell, coiling to the right or left (Kuroda et al., 2009). Another important cue for setting-up the ordered pattern of cell division is often provided by the primary axis of the egg (the animal vegetal axis), since this axis frequently prefigures the anterior-posterior axis of different larva (Peng et al., 2017). One reason for orchestrating cell division axes relative to the primary egg axis is that gastrulation inducing factors, localized for example to the vegetal cortex of the fertilized egg, can be delivered to specific cells. These factors may be RNAs tethered to the cortex as in the ascidian (Prodon et al., 2007), or the protein Dishevelled that is localized to the egg vegetal cortex in the sea urchin (Peng and Wikramanayake, 2013; Weitzel et al., 2004). These vegetal domains are segregated in a nonrandom manner to daughter cells, and many embryos position the first three cleavages such that at the 8cell stage vegetal determinants are segregated to the vegetal tier of 4 cells (Nishida, 1996; Nishida and Sawada, 2001; Peng and Wikramanayake, 2013). The three examples below highlight how the early cell division patterns can influence either the adult body shape or the developmental potential of the embryo:

1.) If surface tension controlled cell placement in spiralian embryos at the 8-cell stage, we might expect the early embryo to look like an aggregate of soap bubbles, as proposed by Robert in 1903 . But instead, the small bubbles do not align like micromeres do, so something is missing (Fig. 1A). Furthermore, recent investigations have revealed that a remarkable correlation exists between spindle orientation pattern, position of the first tier of 4 micromeres at the 8 cell stage and the left or right hand spiral direction of the shell in the adult Pond snail Lymnaea stagnalis (Kuroda et al., 2009; Shibazaki et al., 2004). Identification of the locus underlying this chiral behavior has led to the actin-binding protein Diaphanous, one form of which is expressed maternally only in dextral animals, as likely playing a crucial role in creating the dominant or dextral form of the adult (Kuroda et al., 2016). Diaphanous is thought to create the kink in 

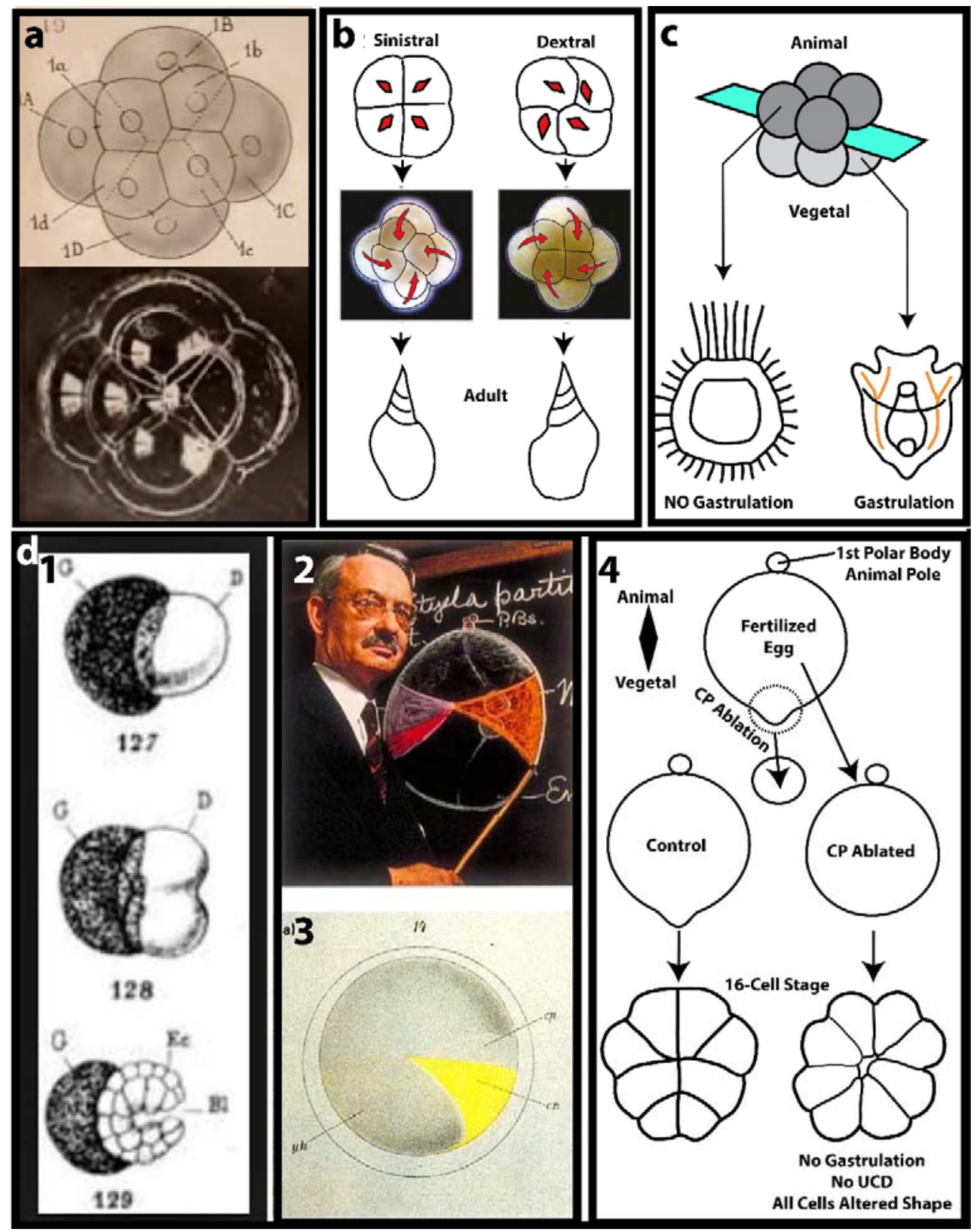

Figure 1. Cell position, maternal determinants, and developmental potential. A. Drawing and Soap bubble pattern that resembles 8-cell stage spiralian (from Robert (1903)). Note that upper small 4 bubbles do not align in grooves of lower 4 larger bubbles. B. Pond Snail. Spindle position (red) and cleavage orientation (red arrows) at the 4 to 8 cell stage in Pond snail blastomeres correlates with positioning of first four micromeres and ultimately with spiral direction of the adult shell. C. Sea urchin. Bisecting sea urchin embryos at the 8-cell stage to create an animal tier or a vegetal tier of 4 cells. The animal tier does not gastrulate and forms a dauerblastula while the vegetal tier does gastrulate and forms a small pluteus larva. D. Ascidian. (1). Ascidian blastomere ablation at 2-cell stage (Chabry, 1887) gives half embryo rather than whole embryo. (2). Conklin (1939) indicating the location of the crescent (mesoplasm) which contains the muscle determinant Macho-1 and the UCD determinant or CAB. (3). Yellow crescent in fertilized ascidian egg. (4). Contraction pole (CP) ablation in fertilized egg abolishes UCD and radializes the embryo. CP ablation also prevents gastrulation. 
the cortex (Fig. 1B) that in turn alters spindle position creating a right handed spiral rather than the left handed one. Of course, cell shape, cell-cell contact and UCD also play important roles.

2.) Sea urchin embryos bisected at the 8-cell stage to create 4 blastomere animal or vegetal halves of the embryo behave quite differently from one another (Driesch, H, 1908; Driesch H, 1892). For example, the animal blastomeres create an embryo that never gastrulates (a dauerblastula) while the vegetal blastomeres do gastrulate and create small but relatively normal larva (Fig. 1B). One reason for this difference is that the vegetal cortex is inherited by the vegetal blastomeres and contains determinants that trigger both UCD and gastrulation. Ettensohn and Wikramanayake elegantly showed that Dishevelled protein (localized to the egg vegetal cortex) may be the gastrulation determinant in echinoderms (Peng and Wikramanayake, 2013; Weitzel et al., 2004).

3) At the dawn of experimental embryology Laurent Chabry (Chabry, 1887) destroyed one blastomere at the 2-cell stage in ascidians. The remaining blastomere did not make a whole embryo (Fig. 1,D1) indicating that some reduction in developmental potential had already occurred. Fertilization in ascidians triggers the first phase of ooplasmic segregation culminating in the formation of a vegetal protrusion that contains both the gastrulation determinant and the unequal cleavage determinant (Fig. 1,D4). The second phase of ooplasmic segregation moves the myoplasm and CAB (centrosome-attracting body: this causes UCD, covered in Section 5) to the posterior pole of the zygote whereas the gastrulation determinant remains in the vegetal pole (Fig. 1,D2-3). Thus, ablation of the vegetal contraction pole (CP), when both determinants are localized together in the fertilized egg, radializes the embryo and prevents gastrulation (Dumollard et al., 2017; Nishida, 1996). The earliest cleavages in ascidian embryos thus distributes maternal determinants to specific cells (Kumano and Nishida, 2007; Nishida and Sawada, 2001; Prodon et al., 2007). 


\subsection{Division plane positioning rules, a historical perspective}

Many different cues control the position of the mitotic spindle in cells causing them to divide symmetrically, unequally or in specific oriented patterns. These cues are additive and in some cases one or more cue dominates over the others (Minc and Piel, 2012; Pietro et al., 2016). Below we will review the rules of cell division laid down at the end of the $19^{\text {th }}$ century by Sachs (Sachs, 1887), and Hertwig (Hertwig, 1884). More recently, modifications of these rules have been made (Minc et al., 2011; Pierre et al., 2016), plus molecular cues have been discovered that influence the position of the mitotic spindle and hence the cell division axis.

Cells of embryos adhere and thus integrate the forces of cell adhesion and the effective surface tension to become particular shapes thereby creating the overall shape of the early embryo (Turlier and Maître, 2015), but embryos also alter their overall shapes through cell division and other dynamic cellular processes as they develop. See the insightful review by D'Arcy Thompson (Thompson, 1942), chapters VII and VIII) and also the beautiful soap bubble aggregates that almost completely recapitulate the pattern of cells in early spiralian embryos (Fig. 1A, Robert, A. "Sur le Développement des Troques" (Robert, A, 1903)).

E.B. Wilson considered the sphere to be the most important starting form since it represents the typical shape of the egg , even though other egg shapes are also known. He considered the pattern of cell division in the sea cucumber to conform to Sachs's rule (Sachs, 1878, 1887). Sachs's rule states that "Each successive cleavage division is at right angle to the earlier". First formulated for plant cells, the embryos of the sea cucumber Synapta display a beautiful example of Sachs's rule. If first and second division are considered vertical and at right angles to each other and the third cleavage is horizontal, again at right angles to the first two divisions, this creates an 8-cell stage embryo which is composed of two tiers of 4 cells. However, Sach's rule was descriptive rather than mechanistic. Oskar Hertwig provided the missing piece of mechanistic information concerning the spindle (Hertwig, 1884). Hertwig's rule stated that "The 
axis of a mitotic spindle occupies the longest axis of the protoplasmic mass in which it lies and division therefore tends to cut this axis transversely". Thus, with reference to Synapta, the first three cell divisions were caused by the Hertwig rule which has come to be known as the "Long Axis Rule" of cell division. Hertwig further tested this rule experimentally by compressing Xenopus eggs showing that the cleavage plane could be artificially redirected to bisect the cell mass according to the new Long Axis in these compressed cells (Hertwig, 1893, see English review of work in Wilson (Wilson, E. B, 1896, 1905,1915)). A recent re-evaluation of the Long Axis Rule demonstrated that the cleavage plane actually cuts through the geometric center of the cell rather than precisely at right angles to the longest axis Wilson (Wilson, E. B, 1896). However, although the first three divisions often follow Sachs's rules, embryos then deviate from this rule and display cell divisions that can be unequal and/or oriented away from the Hertwig Long Axis, as well as being asynchronous, all of which can control the final position of cells in the embryo.

In the following sections we will review three aspects of cell division: unequal cell division (UCD), oriented cell division (OCD) and cell cycle asynchrony. In the final section we will consider all three aspects of cell division together the redistribution of forces throughout the embryo via cell-cell contact and how they relate to formation of the ascidian blastula-stage embryo.

\section{UNEQUAL CELL DIVISION}

Cells display many types of UCD that are mediated by a variety of mechanisms and organelles including positioning by yolk, formation of polar lobes by cortical contraction (in some spiralians), cortical microtubule attracting sites (e.g. Drosophila neuroblasts and C. elegans zygotes), mitotic aster asymmetries (some spiralians), and cortical sites that favor microtubule depolymerization (ascidians, see discussion in section 5). 


\subsection{Effect of yolk on UCD}

Many early embryos display UCD at various points in their embryogenesis which violate Hertwig's rule. These UCDs can be extreme or more subtle. Pfluger's rule (see Wilson, EB. (Wilson, E. B, 1896) for a commentary), applies to the more subtle types of UCD, displayed for example by the formation of larger vegetal blastomeres in Xenopus 8-cell stage embryos. Pfluger's rule states that "During cleavage, formation of spindle fibres takes place in the region of lesser resistance or less yolk". Xenopus eggs are large (circa $1 \mathrm{~mm}$ in diameter) and have copious amounts of yolk that displays an increasing gradient from the animal to the vegetal pole. During early cleavage divisions, vegetal or yolk-rich blastomeres are created larger than animal blastomeres. Cephalopods, birds, reptiles and fish embryos illustrate the extreme case for the effect of yolk, whereby cell division occurs in a meroblastic fashion atop a mass of non-dividing yolk (Hasley et al., 2017). Hertwig tested the effect of yolk on cell division by centrifuging Xenopus eggs thus concentrating the yolk to one side of the egg. He was able to create meroblastic cleavages akin to fish embryos in these centrifuged Xenopus eggs (Hertwig, 1898, see Wilson E.B. (Wilson, E. B, 1896) for a discussion). A recent re-evaluation of the cell shape rule combined with yolk distribution could recapitulate the ordered pattern of early cell divisions in sea urchin, ascidian, Xenopus and fish embryos (Pierre et al., 2016). In fish embryos, an elegant model based on cell shape dictating cell division axis (that is robust yet evolvable since it adapts for example to the size of the yolk sac) recapitulated the ordered sequence of cell divisions of all the blastomeres sitting atop the mass of non-dividing yolk (Xiong et al., 2014). The authors suggested that altering molecular properties controlling cell shape during development could play a pivotal role in the evolution of epithelia thickness and buckling (Xiong et al., 2014). In addition to control of division axis, by altering cell shape or yolk distribution, cells have also evolved additional more extreme versions of UCD that also clearly violate Hertwig's long axis rule. 


\subsection{UCD in Drosophila neuroblast (apicobasal alignment and cortical contraction)}

Much of what we know of UCD comes from work carried out on Drosophila neuroblasts. Neuroblasts are the founder stem cell population from which most neurons are derived in Drosophila, and they form during several rounds of asymmetric cell division that produce one large neuroblast and one smaller ganglion mother cell (Siller and Doe, 2009). The mitotic spindle orients along the apicobasal axis during neuroblast UCD (Savoian and Rieder, 2002; Siller et al., 2006; Siller and Doe, 2008). A protein called Pins (Partner of Inscutable) is a key component of UCD in many cell types. Pins was first identified using a two hybrid screen with Inscutable as bait in Drosophila (Yu et al., 2000). Pins is normally localized to basolateral cell surfaces, but in neuroblasts becomes apical by interactions with Inscutable and Bazooka (PAR3) (Schaefer et al., 2000). NuMA is another key protein in spindle orientation. First identified as a nuclear matrix protein (Lydersen and Pettijohn, 1980), NuMA was subsequently found to bind cytoplasmic dynein and dynactin (Merdes et al., 1996) and to the mammalian Pins homologue LGN (Du et al., 2001). In neuroblasts, the Pins/Mud (NuMA) complex is tethered to the apical plasma membrane via a small G protein, and the Pins/Mud (NuMA) complex was proposed to recruit dynein which pulls on microtubules thus attracting one pole of the mitotic spindle or anchoring one centrosome near the apical cortex causing non-planar spindle alignment. After the first cell division in neuroblasts, where the whole mitotic spindle rotates with one pole being attracted to the apical cortex (Kaltschmidt et al., 2000), the mother centrosome that contains Centrobin becomes anchored to the apical patch of Pins/NuMA, while the smaller daughter centrosome (smaller due to the absence of Centrobin) rotates though $180^{\circ}$ to cause mitotic spindle alignment with the apicobasal axis (Januschke et al., 2013). This centrosome anchoring causes alignment but not displacement of the spindle, and in neuroblasts UCD is due to an additional mechanism. At the basal cortex of the neuroblast, a cap rich in Myosin-2 is capable of causing UCD even when the mitotic spindle is artificially rotated parallel to the apical cortex, resulting in a three daughter cell outcome: two daughter cells are created by a mitotic spindle-based mechanism and thus receive half of the chromatids 
each while a third cytoplasmic mass that lacks chromatids buds off due to the cortical Myosin-2 cap (Cabernard et al., 2010). One view of UCD in neuroblasts is thus that the spindle orients according to the apical-basal polarity of the cell due to the action of the apical Pins/NuMA complex, and that UCD is created by the basal Myosin-2 cap that directs the cleavage furrow away from the spindle mid-zone.

\subsection{UCD in C.elegans zygotes (cortical pulling)}

C.elegans provided the evidence that cortical pulling forces move the spindle towards the cortex to create unequal sized daughter cells. The first cell division in C.elegans zygotes creates a smaller posterior blastomere due to mitotic spindle movement towards the posterior cortex brought about by pulling forces generated at the posterior cortex (Grill and Hyman, 2005). By cutting the mitotic spindle in half using a laser, pulling forces were clearly demonstrated that could move half of the severed mitotic spindle towards the posterior cortex (Fielmich et al., 2018; Grill et al., 2003, 2001). Genetic and RNAi-based experiments revealed that a posterior cortical Galpha/GPR-1/2 (Pins)/LIN-5 (NuMA) complex pulls the mitotic spindle towards the posterior of the dividing cell (Gönczy, 2008; Kotak and Gönczy, 2013). It has been postulated that the actomyosin cortex could provide a stable platform for the plasma membrane force-generating complexes (Pins/NuMA) to interact with the plus ends of astral microtubules (via dynein) thus causing the spindle to be pulled rather than the plasma membrane to invaginate into the asters. Indeed, by weakening the actomyosin cortex, plasma membrane invaginations that represent a proxy for force-generating cortical sites could be observed at the posterior end of the 1-cell embryo rather than spindle movement (Redemann et al., 2010). These membrane invaginations can also be observed in C. elegans zygotes naturally, in the absence of actomyosin perturbation (Fielmich et al., 2018).

\subsection{UCD in zygotes of spiralians (cortical contraction or asymmetric asters/pushing model)}

Some spiralian embryos display UCD during their first cell cycle and also common in the literature are examples of UCD occurring at the 4 to 8 -cell stage to create a tier of four smaller animal micromeres (discussed above for Pond snails). 
The first cell division in mollusks can be unequal and caused by the formation of a large polar lobe during mitosis that transmits determinants to the larger CD cell (Conrad and Williams, 1974). Amongst the annelids a different type of UCD occurs in the zygote, where the segregation of teloplasm to the larger daughter cell can be generated though a mechanism independent of the cortex that depends on centrosome asymmetry. For example, UCD in Tubifex during the first cell division is caused by a highly asymmetric mitotic apparatus that contains only one aster (Shimizu et al., 1998) of maternal centrosome origin (Ishii and Shimizu, 1997). In another species of annelid such as in the Leech Helobdella, the mitotic aster is also asymmetric during the first cell division. However, in Leech the centrosomes are of paternal origin and the mitotic aster asymmetry occurs at metaphase when one centrosome of the mitotic spindle loses gamma-tubulin (Ren and Weisblat, 2006). This leads to the transient disassembly of microtubules of one aster causing that aster to become smaller than the other (Ren and Weisblat, 2006). Low doses of the microtubule destabilizing drug nocodazole, which perturbs microtubule polymerization but not aster asymmetry, abolished spindle migration (indicating that displacement in the direction of the smaller aster is powered by microtubule polymerization?), and thus led to equal cell division rather than UCD (Ren and Weisblat, 2006). Moreover, no cortical site could be identified that influenced spindle alignment (Nelson and Weisblat, 1992). One possibility is that the intact array of astral microtubules at the other pole push the spindle, however one current view is that microtubule-based pushing cannot power spindle displacement in large cells because long microtubules buckle. In support of pushing, a more recent reevaluation of large asters has indicated that they also contain branched microtubules (Ishihara et al., 2014), thus suggesting that a pushing-based mechanisms could potentially operate. Moreover, it has been argued that even in large cells (circa $50 \mu \mathrm{m}$ ) microtubule pushing forces can center centrosomes, and indeed that the pushing force per individual polymerizing microtubule $(5-10 \mathrm{pN})$ is equivalent to dyneinbased (1-7pN) pulling forces (Howard and Garzon-Coral, 2017). Thus, in Leech zygotes the cytoplasmic pulling-based mechanism for mitotic spindle centering may not operate, since the whole mitotic apparatus 
moves in the direction of the shortest microtubules, i.e. in the opposite direction to the prediction (Minc et al., 2011).

\subsection{UCD in sea urchin (cortical pulling?)}

Sea urchin embryos create small vegetal micromeres at the 8 to 16 -cell stage. The pattern of cell division in sea urchins is predictable in that vegetal blastomeres inherit the vegetal cortex of the egg where Dishevelled protein is localized (Peng and Wikramanayake, 2013; Weitzel et al., 2004). However, it is not clear how the orientation of the first two cleavage divisions are specified such that the vegetal cortex is partitioned to the lower tier of 4 cells at the 8-cell stage (the orientation of the third cell division is cued by the first two divisions as predicted by Sachs). It is also unknown how micromeres are formed at the vegetal pole of the embryo at the 8 to 16 -cell stage. However, an intrinsic timing mechanism appears to exist since the vegetal cortex loses pigment granules during micromere formation at the 8 to 16 -cell stage, even in cleavage arrested fertilized eggs (Schroeder, 1980). Concerning the molecular mechanism controlling UCD in sea urchin, an orthologue of the LGN/Pins protein was found to be involved (Voronina and Wessel, 2006). How the vegetal cortical enrichment of Pins/LGN is triggered at the 8-cell stage to cause UCD is not known, although it is tempting to speculate that it has something to do with the intrinsic timing mechanism that induces the loss of pigment granules from the vegetal cortex. It is also interesting to note that the cortical polarity protein aPKC, which is generally apical (outside cortex), is specifically excluded from the micromeres and the vegetal cortex to which the centrosome migrates (Prulière et al., 2011). Centrosomes also display a striking asymmetry during UCD in sea urchin embryos, whereby one centrosome is flattened upon the cortex that will become the micromere (Holy and Schatten, 1991). It is currently unknown what causes this extreme form of centrosome asymmetry somewhat reminiscent of the centrosome asymmetry caused by the absence of Centrobin from the daughter centrosome in Drosophila neuroblasts (Januschke et al., 2011). 
Overall, many of the extreme (non-yolk-based) forms of UCD employ either alignment of the spindle with apicobasal polarity cued by Pins/NuMA (neuroblast), cortical pulling of mitotic spindles (C.elegans), the generation of asymmetric asters via centrosome-based mechanisms (spiralians and neuroblasts), or cortical sites that depolymerize microtubules of one aster (ascidians, see section 5).

\section{ORIENTED CELL DIVISION}

Another feature of cell division in embryos is that spindles often align parallel (or planar) to the apical (outside) surface of the blastomeres even in defiance of the long axis rule. Here OCD is defined as a cell division that does not always obey Hertwig's long axis rule yet still produces daughter cells of roughly equal size (e.g. see OCDs for ascidian embryos in section 5). Since planar cell division is also a conserved aspect of epithelia/endothelia, where cells divide within the sheet of the tissue, it is possible that some aspects of planar cell division in embryos are similar to planar cell division in epithelial sheets. However, since early embryos do not display mature epithelial sub-cellular architecture (e.g. junctions are maturing) and contain yolk there are also likely to be key differences.

\subsection{Planar OCD in epithelia/endothelia}

Two key aspects of planar spindle orientation in epithelia/endothelia are that 1) LGN is excluded from the apical membrane and 2) the Dlg/LGN/NuMA complex becomes enriched on basolateral membranes during mitosis.

In mammalian tissue culture MDCK cells Gai GDP (the plasma membrane tethered partner of LGN) is found both on the apical and basolateral cortical domains yet LGN is localized only to basolateral domains. It has been shown that apical aPKC phosphorylates LGN (on ser 401, causing 14-3-3 proteins to associate with LGN), thus displacing LGN from apical cortex (Hao et al., 2010). In Caco-2 cells LGN is also removed from the apical cortex by the aPKC complex (Par3/Par6/aPKC). For example, aPKC or Par6B depletion both result 
in spindle mis-orientation in Caco-2 cells (Durgan et al., 2011). Similarly, in MDCK cells, silencing of Par3 also causes spindle misalignment and LGN to become recruited to the apical cortex (Hao et al., 2010). Finally, aPKC mediated Pins (LGN) apical exclusion appears to be conserved in Drosophila wing discs, since temperature sensitive mutants of aPKC revealed that $\mathrm{aPKC}$ is required for planar spindle orientation and apical exclusion of Pins (Guilgur et al., 2012). These various findings reveal how LGN is removed from the apical membrane, but they do not explain how LGN becomes enriched in the basolateral membrane in mitosis.

In Drosophila epithelia (wing and follicular) Aurora kinase (A and B) phosphorylation of basolateral Lgl (lethal giant larvae) leads to the basolateral recruitment of Pins/LGN in mitosis. During interphase Lgl is removed from the apical cortex by aPKC and localizes exclusively to the basolateral cortex where it binds Dlg (Discs Large), an apicobasal polarity protein (Bell et al., 2015). During mitosis additional phosphorylation of $\mathrm{Lg}$ by Aurora kinases A and B cause dissociation of $\mathrm{Lg}$ f from Dlg thus providing a temporal switch for Pins to bind Dlg now free of Lgl (Bell et al., 2015; Carvalho et al., 2015).

This DIg mechanism is conserved in chick and human cells. In chick neuroepithelia LGN binds to basolateral Dlg1 (Saadaoui et al., 2014). Moreover, Dlg1 is also recruited to the cortex in HeLa cells during mitosis and its recruitment is necessary for LGN cortical recruitment opposite each spindle pole (Saadaoui et al., 2014). Thus, basolateral mitotic cortical recruitment of the Dlg/LGN/NuMA complex together with apical exclusion of LGN appear to be well-conserved mechanisms for spindle orientation.

However, there are exceptions to this general rule involving apical aPKC and the lateral Dlg/Pins/Lgl pathways that align spindles along the planar axis in epithelia. A reinvestigation of Drosophila wing disc epithelium revealed that neither aPKC nor the Dlg/Pins/Lgl pathways are involved in planar spindle orientation, but Mud/NuMA is still required (Bergstralh et al., 2016). Another example comes from Drosophila pupal notum epithelia. Here the cells round-up during mitosis and cells that were previously stretched in one direction during interphase due to tissue tension lose this long cell shape cue for cell 
division along that axis. How then do mitotic cells remember the direction of tissue tension/stretch during mitosis so that they divide along that axis? In the pupal notum, a mechanism transmits a memory of the anisotropic interphase cell shape to the rounded-up mitotic cell. This memory consists of tricellular junctions (TJs) which align with tissue tension during interphase. Mud/NuMA is localized to these interphase TJs independently of Pins/LGN (Bosveld et al., 2016). Importantly, the foci of cortical Mud/NuMA remain in place during mitotic cell rounding thus providing a mitotic memory of interphase cell shape to align the spindle during mitosis along the axis of tissue stretch (Bosveld et al., 2016). It is interesting to note that this function of maintaining an interphase memory of some spatial cue during mitosis is somewhat similar to the effect retraction fibres have on spindle alignment in adherent HeLA cells during mitosis (Théry et al., 2007).

\subsection{Planar Oriented Cell Division In Embryos}

What processes cause spindles to align parallel to the outside or apical surface of the embryo? Is apicobasal polarity involved as it is in many epithelia?

In Nematostella (a cnidarian) embryos, apicobasal polarity is evident at or before the 16-cell stage (Ragkousi et al., 2017). These embryos display a hollow blastula in which spindles align parallel to the outside of the embryo. LgI was demonstrated to localize to the basolateral cortex both in interphase and mitosis (Ragkousi et al., 2017), however it is not known whether the LGN/NuMA complex is involved in planar spindle orientation in these embryos.

In syncytial Drosophila embryos mitotic spindles also align parallel to the outside of the embryo. Even though individual cells are not formed, the cortex curves out from each nucleus and Dlg is found to be localized at the intersection between these dimples of cortex (Hirashima et al., 2018).

During gastrulation in Xenopus, the mechanism of planar spindle orientation during epiboly depends on apicobasal polarity. Here planar spindle orientation is precisely controlled by counteracting forces 
involving an apical directed force provided by microtubules and Myosin-10 and a basal directed force provided by actin and Myosin-2 (Woolner and Papalopulu, 2012). Again, it is not clear what role the LGN/NuMA complex plays in these embryos.

Although planar spindle orientation is a well-conserved feature of many embryos, it should be noted that not all early embryos display planar oriented spindles. In mouse embryos, the first symmetry breaking event creates the inner cell mass (ICM) and the trophectoderm (TE). Unlike epithelia and most early embryos, spindles can align perpendicular rather than parallel to that apical cortex. Daughter cells that inherit the apical domain become TE while those that do not become ICM (Korotkevich et al., 2017). It was demonstrated that blastomeres that inherit the apical domain have less contractility and remain in the TE while apolar cells are more contractile and have a tendency to become actively internalized (Maître et al., 2016). This creates a dynamic form of cell sorting allowing mouse embryos to regulate the total number of ICM versus TE. Therefore, the position of cells in mouse embryos does not depend only on cell division axis, but also upon an interphase cell internalization mechanism unlike spiralian, urchin or ascidian embryos.

\section{CELL CYCLE ASYNCHRONY}

Perhaps less obvious than UCD and OCD, asynchronous cell cycles can also affect spindle position and thus cell position in some embryos. Cell division involves drastic changes in cell shape caused by mitotic cell rounding. In epithelia, such intrinsic cell shape changes can generate tissue stress and promote, for example, epithelial invagination (Kondo and Hayashi, 2013). Alternatively, mitotic cell rounding is not complete in some epithelia and can be biased/inhibited by tissue tension resulting in OCDs driven by anisotropic cell shape (Campinho et al., 2013; Kong et al., 2017). Cell cycle asynchrony is long known to be necessary for gastrulation movements, whether they consist of epithelial invagination (Drosophila, Xenopus, ascidians, sea urchin primary invagination, some jellyfish (Nematostella) or cell 
ingression/delamination (Zebrafish, sea urchin, some cnidarian e.g. Clytia). In contrast, whether cell cycle asynchrony contributes to shaping the blastula prior to gastrulation is less well known.

Cell cycle asynchrony arises during the midblastula transition (MBT) in the form of meta-synchronous mitotic waves in zebrafish (Olivier et al., 2010). These mitotic waves are also observed in sea urchin blastula, but they do not seem to play a role in embryonic morphogenesis (Parisi et al., 1978). At the early gastrula transition (EGT), mitotic domains (i.e. part of the embryo where the cell cycle is regulated as an independent unit) appear in the freshly patterned germ layers. The first recognizable mitotic domain is a cluster of blastomeres undergoing gastrulation movements (bottle cells) which delay entry in mitosis by introduction of a long G2 phase (Bouldin and Kimelman, 2014).

The cell cycle asynchrony observed at MBT in Xenopus or zebrafish is variable between individuals and reflects the period during which maternal control wanes and zygotic gene expression starts to support cell proliferation (Kane and Kimmel, 1993; Newport and Kirschner, 1982). During this time, the largest blastomeres cycle faster than the smallest ones as they contain more maternal factors for DNA replication such as Cut5, RecQ4, Treslin and Drf1 in Xenopus (Collart et al., 2013; Newport and Kirschner, 1982) or more maternal cyclin B3 transcripts as in the ascidian (Treen et al., 2018) to support DNA replication and mitotic entry. This correlation between cell size and cell cycle timing has also been observed in sea urchin but the mechanisms are completely unknown (Duncan and Whiteley, 2011).

\section{THE ASCIDIAN MODEL}

Ascidians belong to the Tunicata subphylum and are a sister group of vertebrates (Fig.2, Delsuc et al., 2006). Ascidian embryos have taken the concept of regulating cell and spindle position to the extreme 

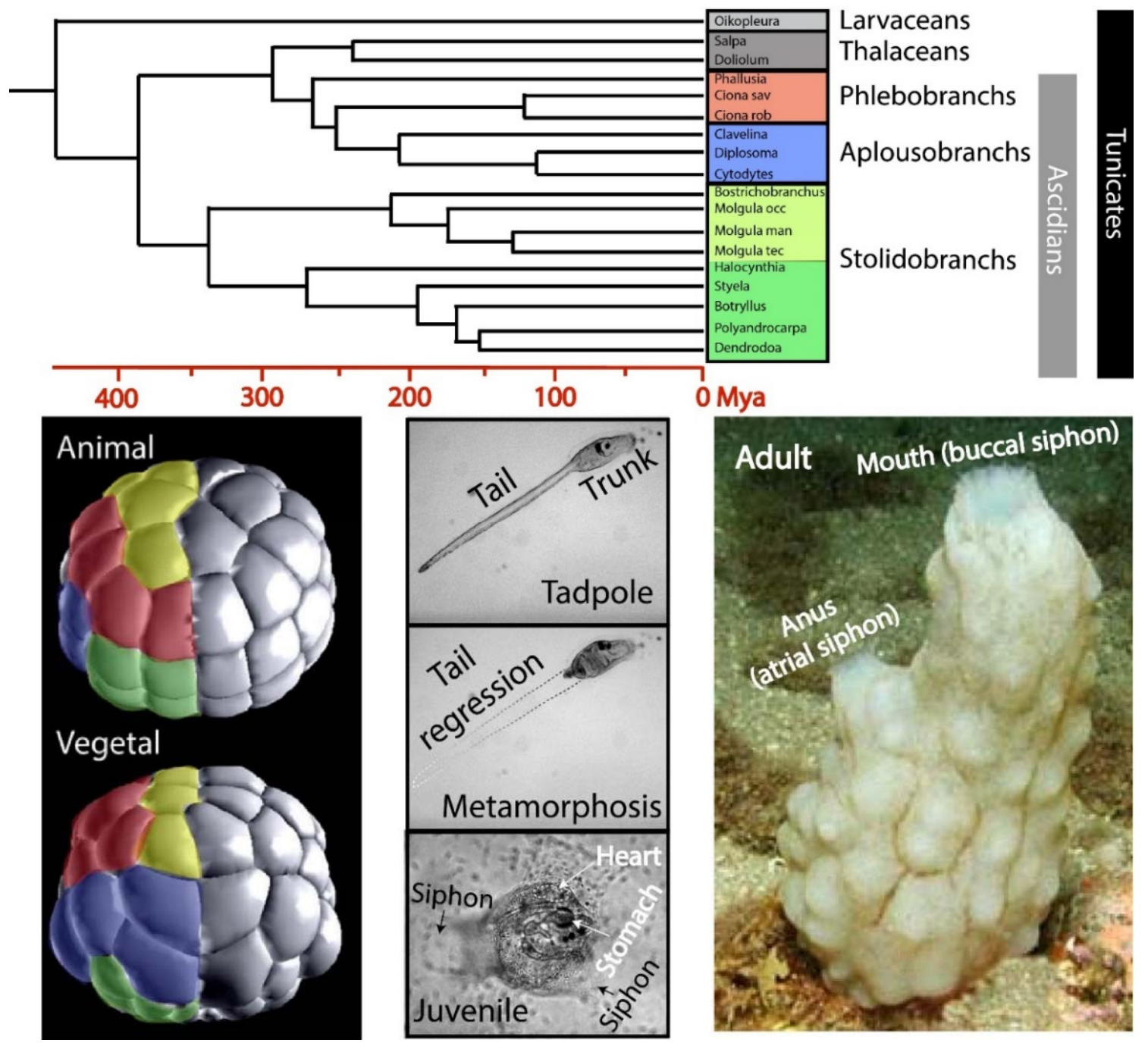

Figure 2. Tunicate phylogeny, invariant cleavage pattern and life cycle. Tunicate tree showing the three groups of ascidians shown (phlebobranchs, aplousobranchs and stolidobranchs). Timeline is displayed below tree, Mya is million years ago (from Delsuc et al., 2018). Interestingly, the pelagic non-ascidian thalaceans group with the benthic ascidians (see Delsuc et al., 2018 for details). Ascidian embryo (Phallusia mammillata) at the 64-cell stage. Cells of the same color represent the 4 grand-daughter cells from the 16-cell stage. Note that some cells form patterns of squares, other lines and other a T-pattern. See Fig. 7 and Dumollard et al (2017) for a thorough explanation of this phenomenon. About 12 hours after fertilization the embryo forms a swimming tadpole larva. After a variable swimming yet non-feeding stage ( 1 to 2 days) the tadpole sticks down (here to glass) and undergoes metamorphosis accompanied by tail regression (note, this is the same larva as image above). A feeding juvenile then forms, and after about 5 to 6 months for Phallusia mammillata, a sexually mature hermaphrodite adult is created that is covered in a thick tunic composed partly of cellulose and feeds by sucking in sea water and organic matter via the buccal siphon. 
amongst animals, whereby every cell follows an invariant cleavage pattern so that individual cells occupy the same specific territory of the embryo at the 64-cell stage (Fig. 2).

The three axes of the embryo (dorsoventral, anteroposterior, and left-right) can even be recognized in the fertilized ascidian egg due to the presence of colored cytoplasmic domains (Fig. 1,D2,3. (Conklin, 1905). By following the distribution of the colored cytoplasm (in Styela partita), Edwin Conklin was able to produce a complete nomenclature and lineage map up to the gastrula stage (Conklin, 1905). Given that the invariant cleavage pattern is the same amongst different species, this nomenclature and lineage map is used by the community working on different ascidians (Fig. 2, e.g. Halocynthia roretzi, a stolidobranch or Ciona robusta and Phallusia mammillata, phlebobranchs). Although ascidian embryos were once considered completely mosaic (or cell-autonomous) in their mode of development, we now know that neural induction at the 32-cell stage requires FGF signaling from vegetal blastomeres to their overlying animal blastomeres (Tassy et al., 2006), and this is the first of many inductions occurring during subsequent development (Lemaire, 2009; Sobral et al., 2009). Thus, cells must be precisely positioned by the cleavage program to enable these subsequent inductive interactions.

We are interested in how the cleavage pattern is regulated during development, not least because the form of the early embryo is a product of cell size, cell number and the interaction between cells. Despite being composed of only 64 cells (one cell cycle before gastrulation begins), the ascidian blastula displays the same fate map as other chordates such as Xenopus, with regions of both embryos displaying the same fate-restricted territories (Sobral et al., 2009), although cell number is less in ascidians by more than one order of magnitude. Ascidians accomplish precise cell positioning in the absence of cell displacement and death, indicating that cell division orientation is key for blastomere positioning. When cell number is so low, UCD of just 2 cells at the 8 to 16 -cell stage can affect the overall shape of the embryo (this would not be the case if it were 2 cells in an embryo with 2000 cells for example). As we have discussed, UCD has thus been exploited by many early embryos not only for segregation of maternal determinants to one of 
the two daughter cells, but also for shaping the early embryo (Fig. 1). Incredibly, even though phlebobranch and stolidobranch ascidians last shared a common ancestor about 400 Mya (Delsuc et al., 2018), they display the same invariant cleavage pattern. Either because of conservation or convergence, this is quite remarkable since it has been estimated that the these two groups of ascidians are as different from each other genetically as fish are from humans (Stolfi et al., 2014).

Implicit in the term invariant cleavage is that every cell in the gastrula will have the same relative position with exactly the same neighboring blastomeres. Curiously, in addition to cell positioning being invariant, cell cycle asynchrony and UCD are also invariant amongst distantly-related ascidians. We therefore exploit these three invariant features of ascidian embryos as a robust experimental system to uncover the cell biological mechanisms that control cell size inequality (UCD), cell number (cell cycle asynchrony), and cell position (OCD).

\subsection{Unequal Cell Division (cortical pulling and microtubule depolymerization)}

UCD in ascidian embryos begins at the 8-cell stage and is caused by the centrosome-attracting body or CAB (Nishikata et al., 1999). The CAB precursor forms during the two phases of ooplasmic segregation following fertilization. The first three cell divisions result in the CAB precursor being inherited by two vegetal posterior blastomeres (B4.1 pair) at the 8-cell stage (Fig. 3).

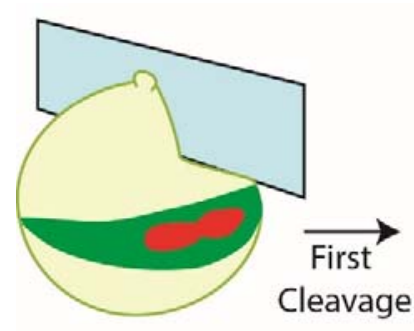

Left and Right

Sides Fixed

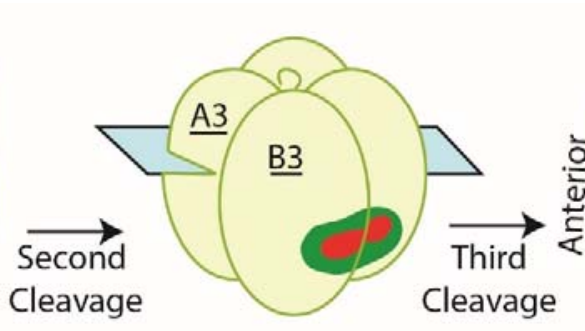

Anterior- A3 pair Posterior-B3 pair

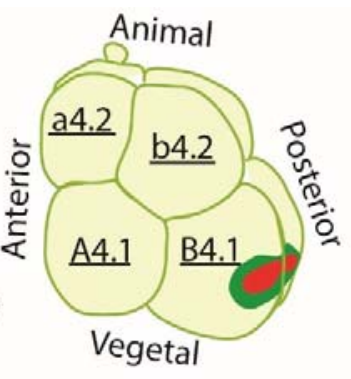

Right Side View

Figure 3. First three cleavages in ascidian embryos. The $C A B$ is colored red and the myoplasm green. 
The $C A B$ causes $U C D$ and patterns the embryo. e.g. surgical removal of the $C A B$ precursor $(C P$, contraction pole) at the 1-cell stage abolishes unequal cleavage and radializes embryos (Dumollard et al., 2017; Nishikata et al., 1999). The CAB first causes UCD starting at the 8-cell stage when two posterior vegetal blastomeres (B4.1 pair) divide unequally (in terms of size) and asymmetrically (in terms of fate) to form two smaller germ-cell precursors at the 16-cell stage. A further two successive rounds of UCD occur in the smaller blastomeres at the 16 and 32-cell stages creating two very small germ-cell precursors at the 64cell stage that each contain one CAB inherited from the B4.1 cells (Fig. 4).

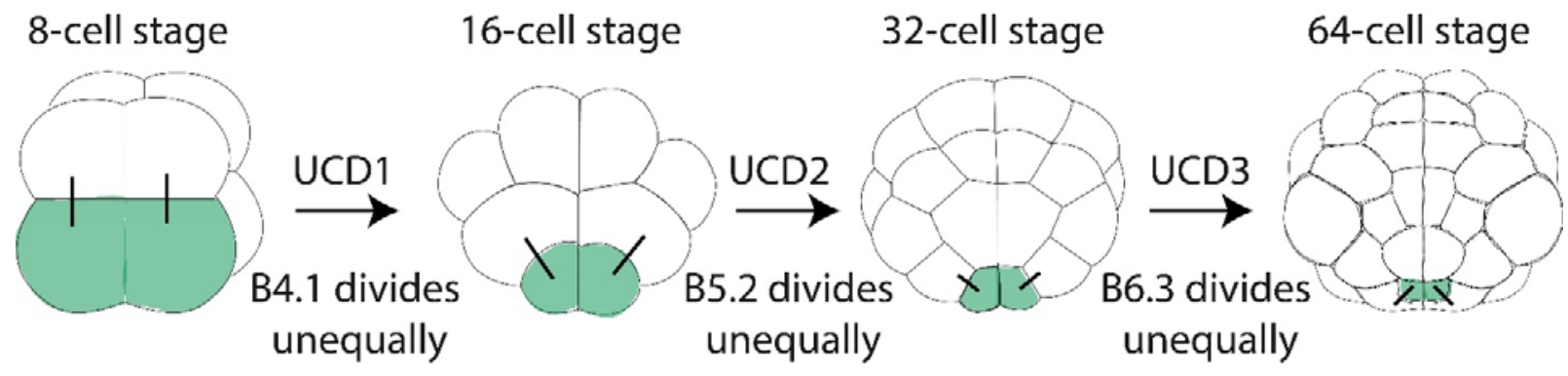

Figure 4. Vegetal view of ascidian embryos showing three successive unequal cell divisions. The pairs of cells containing the 2 CABs are germ-line precursors and are colored green. Dark bars indicate sister cells that give rise to muscle. UCD is unequal cell division.

The CAB generates UCD by causing one spindle pole to move towards the CAB cortex (Nishikata et al., 1999; Prodon et al., 2010). The precise molecular mechanism that causes UCD is not known, although posterior end mark/PEM1 (Negishi et al., 2007), polo-like kinase 1/Plk1 (Negishi et al., 2011), and the microtubule depolymerase Kif2 (Costache et al., 2017) are all thought to be involved. In addition to PEM1's role in UCD, PEM1 also silences transcription (Kumano et al., 2011) in a manner that shares similarity to germline silencing mediated by Pgc in Drosophila (Kumano et al., 2011). Finally, around 40 maternal RNAs termed PEM (posterior end mark) RNAs are tethered to the CAB, some of which like Vasa are involved in germ cell function (Prodon et al., 2007). 
Recently we discovered that a microtubule depolymerase, Kif2 a member of the kinesin-13 family of proteins, is localized to the cortical endoplasmic reticulum that is accumulated in the CAB (Fig. 5). This depolymerizing kinesin lacks motor function and is required for shrinking of the microtubule aster nearest the $C A B$, which we think is permissive for the whole mitotic spindle to approach the $C A B$ since microtubule polymerization would act to counteract spindle movement towards the CAB (Costache et al., 2017). This may be a pushing-based mechanism powered we think by microtubule polymerization of the distant aster (which increases in size as the $C A B$ aster shrinks, Fig. 5), thus pushing the spindle towards the $C A B$ (Costache et al., 2017). However, we also have preliminary evidence for an additional pulling-based mechanism that operates during late mitosis to precisely position one pole of the mitotic spindle adjacent to the CAB near the midline in B5.2 cells (Fig. 5 and manuscript in preparation).

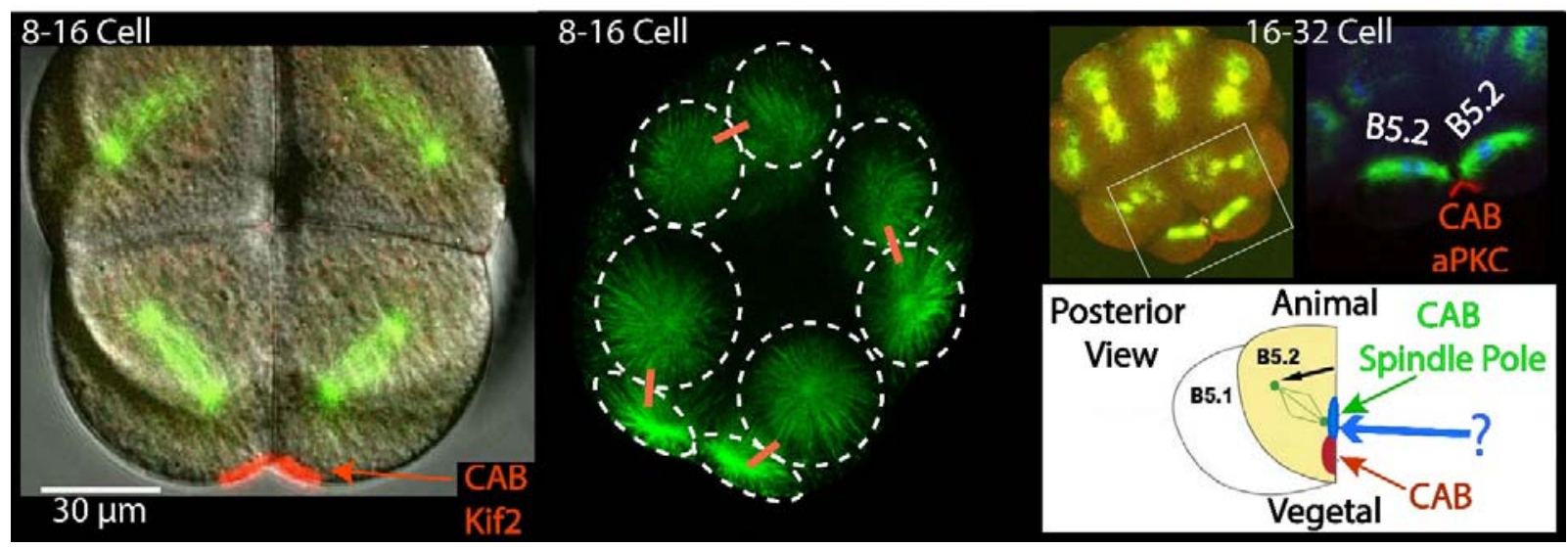

Figure 5. Kif2 localizes to $C A B$ but not to site where spindle poles align. Left image shows the typical localization pattern of Kif2 at the CAB in live embryos (Kif2::tdTomato) during early mitosis at 8-cell stage before spindle displacement (microtubule label EB3::Venus, light green) (see Costache et al., 2017 for full movie). Middle confocal image displays microtubule distribution during late mitosis at 8-cell stage in live embryo (Ens::3GFP). Note size of asters (dotted white circles) and size inequality in two pairs of lower cells. Red bars represents sister cells. Right pair of images (fixed embryos, anti-tubulin: green and antiaPKC: red) show spindle position during mitosis at 16-cell stage. Note that the spindle does not point towards the $C A B$ but rather above the $C A B$ to an as yet unidentified midline cortical domain. The drawing indicates spindle position during mitosis at 16-cell stage and also our hypothesis as to the location of an additional midline cortical domain adjacent to the CAB-spindle pole (blue domain, blue arrow). 


\subsection{Cell Cycle Asynchrony}

Ascidian embryos show an extreme example of how cell cycle asynchrony is tightly regulated already at the MBT and can be compared to C.elegans (which also have an invariant cleavage pattern). In ascidian embryos, the maternal to zygotic transition (MZT) occurs at the 16-cell stage (Treen et al., 2018) at exactly the time endomesoderm and ectoderm are specified. At this stage, germ layer patterning by $\beta$-catenin also patterns the cell cycle in the endomesoderm where nuclear $\beta$-catenin maintains a rapid cell cycle while the overlying animal ectoderm slows down (Dumollard et al., 2013). Such patterned cell cycle asynchrony gives rise to a brief yet crucial 24-cell stage that is found in both stolidobranch and phlebobranch ascidians even though these ascidians last shared a common ancestor approximately 400 million years ago (Delsuc et al., 2018). As will be discussed below, such cell cycle asynchrony is informative to implement not only the temporal aspect of the invariant cleavage pattern but also for spatial aspects (i.e. cell positioning).

Cell cycle asynchrony begins at the 16-cell stage in the ascidian embryo when endomesoderm and ectoderm are specified (Dumollard et al., 2013). At this stage, the 6 endomesoderm blastomeres-in the vegetal half of the embryo enter mitosis 11 minutes before the 8 ectoderm cells of the animal half giving rise to a transient 24 -cell stage. At the 32 -cell stage the 14 vegetal/endomesoderm blastomeres enter mitosis 15 minutes before the 16 ectoderm cells to give rise to a 44 -cell stage preceding the 64 cell blastula (Fig. 6). Strikingly, the 24 or 44 -cell stages have been observed in different orders of ascidians suggesting that such precise cell cycle asynchrony is of vital importance for subsequent ascidian development. The first difference between different ascidian orders is that stolidobranch embryos starts to gastrulate at the 


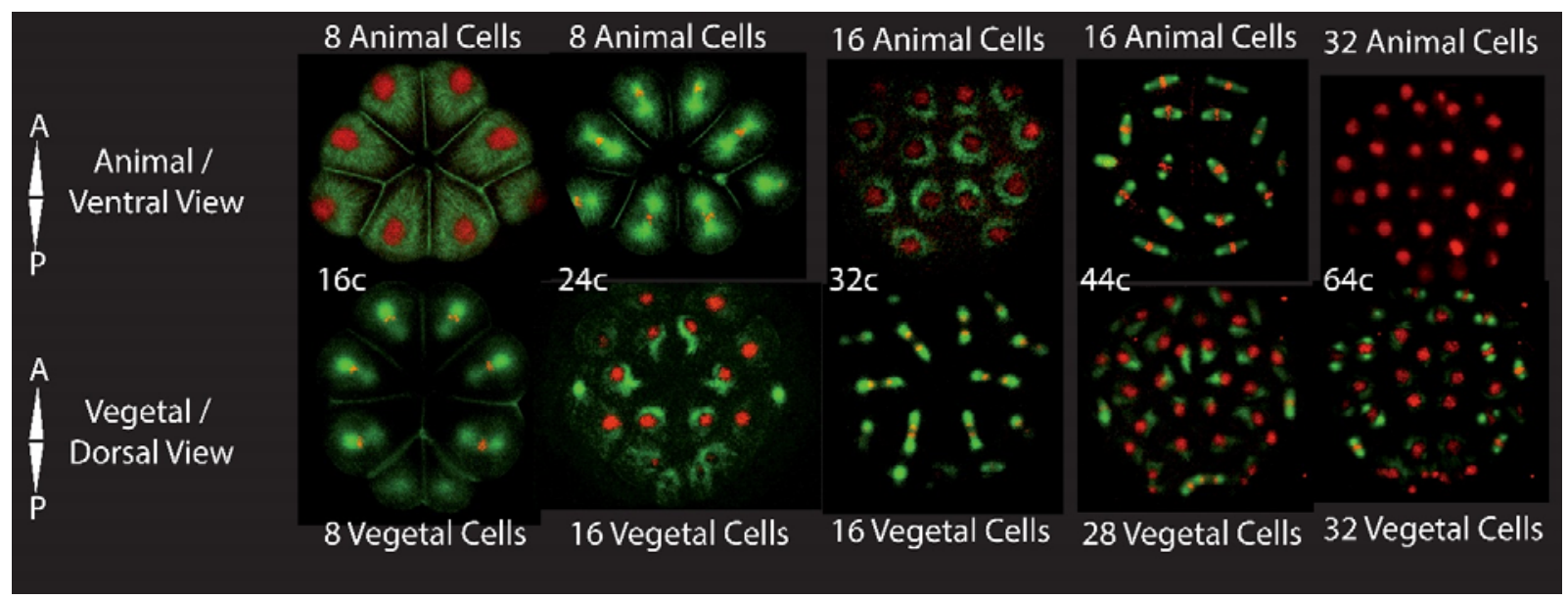

Figure 6. Asynchronous cell cycle in ascidians. Animal and vegetal views of the same embryo (confocal images) from 16 to 64-cell stage. Nuclei and chromosomes are red (Histone H2B::Rfp1) and microtubules green (MAP7::GFP). Note that vegetal cells divide before the animal cells at the 16-cell stage creating a 24-cell stage. This asynchrony is maintained thus creating a 44-cell stage. Note also that at the 32-cell stage the 14 endomesoderm vegetal cells divide before the 16 animal ectoderm cells. The 2 germ lineage cells are slightly delayed thus creating a brief 44-cell stage rather than a 48-cell stage.

110-cell stage whereas gastrulation initiates at the 112-cell stage in phlebobranchs (Lemaire, 2009;

Nishida, 2005).

At the 64-cell stage, some gene-regulatory networks (GRNs) such as the GRN specifying the notochord differs between Halocynthia (Takatori et al., 2010) and Ciona (Hudson et al., 2013), illustrating how conservation of embryonic shape at this stage is stronger than GRN conservation. Thus, a short delay in cell cycle timing equivalent to the duration of mitosis ( $15 \mathrm{~min}$. in Phallusia) appears to have been conserved for around 400 million years (unless of course it has appeared via convergence). It is worth noting that while a mechanism relying on absolute time may vary at differing temperatures, a mechanism relying on cell cycle asynchrony is more robust since it operates over a range of temperatures (Halocynthia embryos develop at $12^{\circ} \mathrm{C}$ while Phallusia embryos can develop at $25^{\circ} \mathrm{C}$ ). We were thus intrigued to understand the importance of this short delay and found that a 15 minutes delay between vegetal and animal halves of the embryo is necessary to maintain an invariant cleavage pattern (Dumollard et al., 2017). Because these alternate cell divisions are shared by distantly-related ascidian species, we surmises that alternate cell 
division has been exploited by ascidian embryos to maintain a precise spatial pattern of cell divisions, which are known to be required to implement cell-contact based neural inductions starting at the 32-cell stage (Lemaire, 2009; Tassy et al., 2006).

\subsection{Oriented Cell Division}

In contract to many cells, ascidian blastomeres do not completely round-up during mitosis (since they maintain some adhesion), which is not entirely without precedent amongst embryos. Spindle orientation in the ascidian embryo thus follows mitotic cell shape, but crucially with an apical constraint.

The ascidian-specific pattern of cell divisions generating the blastula relies on OCDs. All spindles align parallel to the outside or apical surface of blastomeres in ascidians (Fig. 7A), so no cells are internal before gastrulation. However, this is oftentimes not the longest length of the cell (Fig. 7A). Thus, these cell divisions can be considered OCDs as they seem cued by apicobasal polarity rather than Hertwig's long axis rule. We found that apical cell shape dictates spindle orientation, and so all spindles align with the longest length of the apical cell shape. However, at the 32-cell stage some spindles rotate away from their starting position (a6.6, a6.7 and a6.8) while other spindles remain in their starting orientation (e.g. all remaining animal cells, Fig. 7 B,C,D). This is because some spindles are already aligned with the longest apical cell shape at prophase while other are not, and these latter spindles thus rotate into the longest mitotic apical cell shape. Thus, here we define all cell divisions at this stage as oriented by apical cell shape as examples of OCD (Dumollard et al., 2017; McDougall et al., 2015). Strikingly, all these OCDs are generated by the shape of the apical surface of blastomeres and preventing cell cycle asynchrony changes the invariant blueprint of apical cell shapes (Dumollard et al., 2017). 


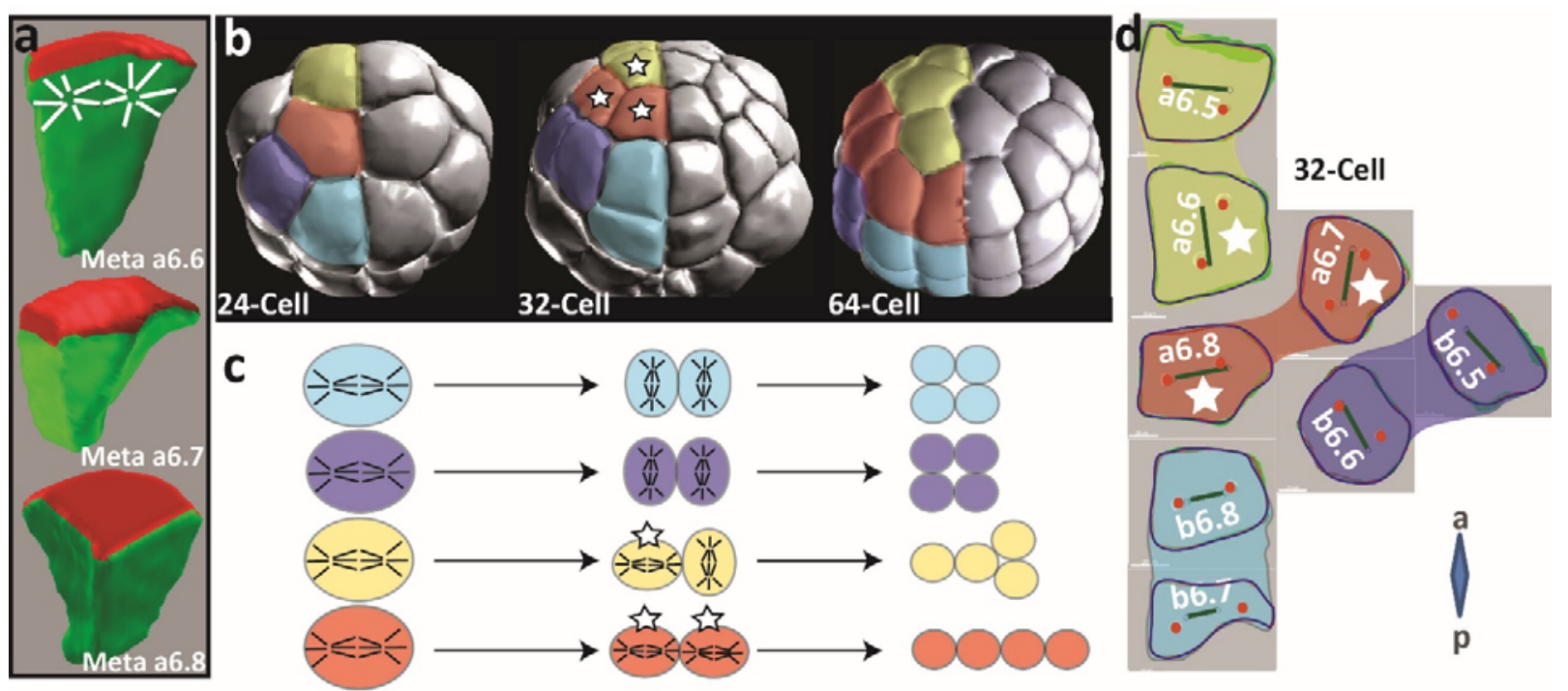

Figure 7. Oriented Cell Division (OCD). A. Three segmented animal cells in metaphase at 32-cell stage (a6.6, a6.8 and a6.8), apical is red and basolateral green. Spindle position parallel to apical surface is indicated (white spindle). Note that spindle does not align with the longest cell length in mitosis but rather with the longest apical length. B. Animal view of 3D representations of fixed embryos at 24, 32 and 64-cell stages. Color coding represents grand-daughter cell quartets at 64-cell stage. White stars indicate a6.6, a6.7 and a6.8. C. Cartoon indicating OCD in all cells as spindles align with longest apical length: default spindle position where spindles are already aligned with longest apical length (blue and violet cells) give squares of 4 cells at 64-cell stage; or spindle rotation into longest apical length (in three cells, white stars) that give T-shape or Line shape at 64-cell stage. Three white stars indicate cells that display spindle rotations (a6.6, 6.7 and 6.8) so that spindles align in same axis as the spindles of their mother cell. D. Segmented apical projections from live 32-cell embryos in which actual spindle pole position is indicated by Red circles, and where Green bars indicate predicted spindle positions based on longest apical length (from computational model Dumollard et al., 2017). White stars again indicate cells in which spindle rotated. Nomenclature of all cells are indicated ( $a=$ anterior, $p=$ posterior).

With regard to the dynamic cell and embryo shape changes occurring during cleavage stages, it is still puzzling how such highly stereotyped cell shapes at metaphase can be so robustly obtained during ascidian blastula formation. Since cell-cell contact observed in ascidian embryos remains high during mitosis, this might explain such a robustness. First, removing cell-cell contact by inhibiting basolateral membrane formation (using dominant active aPKC) or by inhibiting cadherin adhesion (using $\mathrm{Ca}^{2+/} \mathrm{Mg}^{2+}$-free sea water) alters the third cell division generating 8-cell stage embryos of different shapes rather than normal two tiers of 4 cells (Dumollard et al., 2017). We also hypothesize that if all the cells were in mitosis at the same 
time, cell-cell contact would be reduced at the embryo level. In support of this view, ascidian embryos synchronized by inhibiting wee1 (a cell cycle kinase) display a much larger blastocoel during cell divisions than observed in wild type embryos (our unpublished observations), suggesting that cell-cell contact is not as efficiently maintained between animal and vegetal cells in synchronized embryos.

Thus, we propose that a template model maintains the invariant cleavage pattern by propagating forces throughout the embryo via cell-cell contact. The large size of the cell-cell interfaces in the ascidian blastula could allow efficient force transmission throughout the whole embryo. So, alternate vegetal/animal cell divisions and UCD of just two cells in one part of the embryo impacts the global cleavage pattern (Figs 1, $5,6,7)$. Cell-cell contact in the ascidian embryo may then be necessary to transduce forces into changes in apical cell shape at metaphase to drive OCDs. Such cell-cell contacts likely also counteracts forces generated through mitotic cell rounding (mitotic cell rounding occurs in dissociated blastomeres (Prodon et al., 2010) in order to maintain an anisotropic apical cell shape during metaphase.

\subsection{Future directions}

Ascidians thus offer a unique systems-level model where the forces that shape early embryos and their constituent cells can be analyzed using biophysical and cell biological techniques to understand how cleavage patterns lead to embryo shape. Our working model so far is that the effects of UCD (Costache et al., 2017) and cell cycle asynchrony (Dumollard et al., 2013) are propagated throughout the embryo from the 24 to 64-cell stages through cell adhesion and cell shape (Dumollard et al., 2017). Further research is required to determine whether asynchronous cell cycles bring about more internal forces. For example, differential cell contractility between interphasic and mitotic cells would generate a specific pattern of forces throughout the embryo. Moreover, to understand how forces are generated, it would be of great importance to take into account the contractility at the apical surface and both contractility and adhesion at the basolateral surface. However, it may prove difficult to measure contractility of basolateral cortices 
that might be very different from contractility of apical cortices. We surmise that because cells adhere, all the constituent cells of the embryo are affected by what at first appears to be small localized changes such as UCD in two posterior blastomeres or the emergence of the 24-cell stage. We have come to the hypothesis that the shape of all the cells in the early embryo, and in particular the shapes of their apical surfaces, are affected by both UCD and asynchronous cell cycles leading to spindle positioning in the longest apical cell length (Dumollard et al., 2017). The only cells that do not obey the apical cell shape rule are those that divide unequally (Dumollard et al., 2017) due to the localization of molecular cues that position the spindle (Costache et al., 2017). Thus, we note that this is not a full explanation since we do not know how cell adhesion and the mechanical properties of the cells lead to cell and ultimately embryo shape. Another important unresolved question is how all the spindles align parallel with the apical cell surface: ascidian embryos do not have any internal cells before gastrulation. Our thoughts are that this could involve Pins/LGN and NuMA as in epithelia, but we must not forget about subcellular distribution of cytoplasmic domains including the yolk, which occupies the deeper cytoplasm of the blastomeres at this stage of embryogenesis.

\section{Acknowledgements}

We would like to thank Zak Swartz for thoughtful comments that improved the manuscript. We would also like to thank the funding agencies that support our work: the French government funding agency Agence National de la Recherche (ANR "MorCell" : ANR-17-CE 13-0028) and Sorbonne University for supporting the Réseau André Picard. We also thank the CRBM of Institut de la Mer de Villefranche (IMEV) that is supported by EMBRC-France, whose French state funds are managed by the ANR within the Investments of the Future program under reference ANR-10-INBS-02. 


\section{References}

Akiyama, M., Tero, A., Kobayashi, R., 2010. A mathematical model of cleavage. J. Theor. Biol. 264, 84-94. https://doi.org/10.1016/j.jtbi.2009.12.016

Bell, G.P., Fletcher, G.C., Brain, R., Thompson, B.J., 2015. Aurora kinases phosphorylate Lgl to induce mitotic spindle orientation in Drosophila epithelia. Curr. Biol. 25, 61-68. https://doi.org/10.1016/j.cub.2014.10.052

Bergstralh, D.T., Lovegrove, H.E., Kujawiak, I., Dawney, N.S., Zhu, J., Cooper, S., Zhang, R., Johnston, D.S., 2016. Pins is not required for spindle orientation in the Drosophila wing disc. Development 143, 2573-2581. https://doi.org/10.1242/dev.135475

Bosveld, F., Markova, O., Guirao, B., Martin, C., Wang, Z., Pierre, A., Balakireva, M., Gaugue, I., Ainslie, A., Christophorou, N., Lubensky, D.K., Minc, N., Bellaïche, Y., 2016. Epithelial tricellular junctions act as interphase cell shape sensors to orient mitosis. Nature 530, 495-498. https://doi.org/10.1038/nature16970

Bouldin, C.M., Kimelman, D., 2014. Cdc25 and the importance of G2 control: insights from developmental biology. Cell Cycle 13, 2165-2171. https://doi.org/10.4161/cc.29537

Brun-Usan, M., Marín-Riera, M., Grande, C., Truchado-Garcia, M., Salazar-Ciudad, I., 2017. A set of simple cell processes is sufficient to model spiral cleavage. Development 144, 54-62. https://doi.org/10.1242/dev.140285

Cabernard, C., Prehoda, K.E., Doe, C.Q., 2010. A spindle-independent cleavage furrow positioning pathway. Nature 467, 91-94. https://doi.org/10.1038/nature09334

Campinho, P., Behrndt, M., Ranft, J., Risler, T., Minc, N., Heisenberg, C.-P., 2013. Tension-oriented cell divisions limit anisotropic tissue tension in epithelial spreading during zebrafish epiboly. Nat. Cell Biol. 15, 1405-1414. https://doi.org/10.1038/ncb2869

Carvalho, C.A., Moreira, S., Ventura, G., Sunkel, C.E., Morais-de-Sá, E., 2015. Aurora A triggers Lgl cortical release during symmetric division to control planar spindle orientation. Curr. Biol. 25, 53-60. https://doi.org/10.1016/j.cub.2014.10.053

Chabry, L., 1887. Contribution a l'embryologie normale et teratologique des Ascidies simples. J. Anat. Physiol. 23, 167-319.

Collart, C., Allen, G.E., Bradshaw, C.R., Smith, J.C., Zegerman, P., 2013. Titration of four replication factors is essential for the Xenopus laevis midblastula transition. Science $341,893-896$. https://doi.org/10.1126/science.1241530

Conklin, E.G., 1905. The organization and cell-lineage of the ascidian egg. J. Acad. Natl. Sci. Philadelphia. 13.

Conrad, G.W., Williams, D.C., 1974. Polar lobe formation and cytokinesis in fertilized eggs of llyanassa obsoleta. I. Ultrastructure and effects of cytochalasin B and colchicine. Dev. Biol. 36, 363-378.

Cook, C.E., Chenevert, J., Larsson, T.A., Arendt, D., Houliston, E., Lénárt, P., 2016. Old knowledge and new technologies allow rapid development of model organisms. Mol. Biol. Cell 27, 882-887. https://doi.org/10.1091/mbc.E15-10-0682

Costache, V., Hebras, C., Pruliere, G., Besnardeau, L., Failla, M., Copley, R.R., Burgess, D., Chenevert, J., McDougall, A., 2017. Kif2 localizes to a subdomain of cortical endoplasmic reticulum that drives asymmetric spindle position. Nature Communications 8, s41467-017. https://doi.org/10.1038/s41467-017-01048-8

Delsuc, F., Brinkmann, H., Chourrout, D., Philippe, H., 2006. Tunicates and not cephalochordates are the closest living relatives of vertebrates. Nature 439, 965-968.

https://doi.org/10.1038/nature04336 
Delsuc, F., Philippe, H., Tsagkogeorga, G., Simion, P., Tilak, M.-K., Turon, X., López-Legentil, S., Piette, J., Lemaire, P., Douzery, E.J.P., 2018. A phylogenomic framework and timescale for comparative studies of tunicates. BMC Biol. 16, 39. https://doi.org/10.1186/s12915-018-0499-2

Driesch, H, 1908. The 1907 Gifford Lectures. The Science and Philosophy of the Organism. London.

Driesch H, 1892. Entwicklungsmechanische Studien 1. Der Wert der erster Furchungszellen in der Echinodermentwicklung. Experimentelle Erzeugung von Teil-und Doppelbildungen. Z. Zool 53.

Du, Q., Stukenberg, P.T., Macara, I.G., 2001. A mammalian Partner of inscuteable binds NuMA and regulates mitotic spindle organization. Nature Cell Biology 3, 1069-1075. https://doi.org/10.1038/ncb1201-1069

Dumollard, R., Hebras, C., Besnardeau, L., McDougall, A., 2013. Beta-catenin patterns the cell cycle during maternal-to-zygotic transition in urochordate embryos. Developmental Biology 384, 331342. https://doi.org/10.1016/j.ydbio.2013.10.007

Dumollard, R., Minc, N., Salez, G., Aicha, S.B., Bekkouche, F., Hebras, C., Besnardeau, L., McDougall, A., 2017. The invariant cleavage pattern displayed by ascidian embryos depends on spindle positioning along the cell's longest axis in the apical plane and relies on asynchronous cell divisions. Elife 6. https://doi.org/10.7554/eLife.19290

Duncan, R.E.L., Whiteley, A.H., 2011. The echinoid mitotic gradient: effect of cell size on the micromere cleavage cycle. Mol. Reprod. Dev. 78, 868-878. https://doi.org/10.1002/mrd.21373

Durgan, J., Kaji, N., Jin, D., Hall, A., 2011. Par6B and atypical PKC regulate mitotic spindle orientation during epithelial morphogenesis. J. Biol. Chem. 286, 12461-12474. https://doi.org/10.1074/jbc.M110.174235

Fielmich, L.-E., Schmidt, R., Dickinson, D.J., Goldstein, B., Akhmanova, A., van den Heuvel, S., 2018. Optogenetic dissection of mitotic spindle positioning in vivo. Elife 7. https://doi.org/10.7554/eLife.38198

Gehring, W.J., 1996. The master control gene for morphogenesis and evolution of the eye. Genes Cells 1, 11-15.

Gönczy, P., 2008. Mechanisms of asymmetric cell division: flies and worms pave the way. Nat. Rev. Mol. Cell Biol. 9, 355-366. https://doi.org/10.1038/nrm2388

Grill, S.W., Gönczy, P., Stelzer, E.H., Hyman, A.A., 2001. Polarity controls forces governing asymmetric spindle positioning in the Caenorhabditis elegans embryo. Nature 409, 630-633. https://doi.org/10.1038/35054572

Grill, S.W., Howard, J., Schäffer, E., Stelzer, E.H.K., Hyman, A.A., 2003. The distribution of active force generators controls mitotic spindle position. Science 301, 518-521. https://doi.org/10.1126/science.1086560

Grill, S.W., Hyman, A.A., 2005. Spindle positioning by cortical pulling forces. Dev. Cell 8, 461-465. https://doi.org/10.1016/j.devcel.2005.03.014

Guilgur, L.G., Prudêncio, P., Ferreira, T., Pimenta-Marques, A.R., Martinho, R.G., 2012. Drosophila aPKC is required for mitotic spindle orientation during symmetric division of epithelial cells. Development 139, 503-513. https://doi.org/10.1242/dev.071027

Hao, Y., Du, Q., Chen, X., Zheng, Z., Balsbaugh, J.L., Maitra, S., Shabanowitz, J., Hunt, D.F., Macara, I.G., 2010. Par3 controls epithelial spindle orientation by aPKC-mediated phosphorylation of apical Pins. Curr. Biol. 20, 1809-1818. https://doi.org/10.1016/j.cub.2010.09.032

Hasley, A., Chavez, S., Danilchik, M., Wühr, M., Pelegri, F., 2017. Vertebrate Embryonic Cleavage Pattern Determination. Adv. Exp. Med. Biol. 953, 117-171. https://doi.org/10.1007/978-3-319-4609564

Heisenberg, C.-P., Bellaïche, Y., 2013. Forces in tissue morphogenesis and patterning. Cell 153, 948-962. https://doi.org/10.1016/j.cell.2013.05.008 
Hertwig, O., 1884. Untersuchungen zur Morphologie und Physiologie der Zelle: Das Problem der Befruchtung und der Isotropie des Eies, eine Theorie der Vererbung. Fischer.

Hirashima, T., Tanaka, R., Yamaguchi, M., Yoshida, H., 2018. The ABD on the nascent polypeptide and PH domain are required for the precise Anillin localization in Drosophila syncytial blastoderm. Scientific Reports 8, 12910. https://doi.org/10.1038/s41598-018-31106-0

Holy, J., Schatten, G., 1991. Differential behavior of centrosomes in unequally dividing blastomeres during fourth cleavage of sea urchin embryos. J. Cell. Sci. 98 ( Pt 3), 423-431.

Howard, J., Garzon-Coral, C., 2017. Physical Limits on the Precision of Mitotic Spindle Positioning by Microtubule Pushing forces. BioEssays 39, 1700122. https://doi.org/10.1002/bies.201700122

Hudson, C., Kawai, N., Negishi, T., Yasuo, H., 2013. $\beta$-Catenin-Driven Binary Fate Specification Segregates Germ Layers in Ascidian Embryos. Curr. Biol. https://doi.org/10.1016/j.cub.2013.02.005

Ishihara, K., Nguyen, P.A., Groen, A.C., Field, C.M., Mitchison, T.J., 2014. Microtubule nucleation remote from centrosomes may explain how asters span large cells. Proc. Natl. Acad. Sci. U.S.A. 111, 17715-17722. https://doi.org/10.1073/pnas.1418796111

Ishii, R., Shimizu, T., 1997. Equalization of unequal first cleavage in the Tubifex egg by introduction of an additional centrosome: implications for the absence of cortical mechanisms for mitotic spindle asymmetry. Dev. Biol. 189, 49-56. https://doi.org/10.1006/dbio.1997.8653

Januschke, J., Llamazares, S., Reina, J., Gonzalez, C., 2011. Drosophila neuroblasts retain the daughter centrosome. Nat Commun 2, 243. https://doi.org/10.1038/ncomms1245

Januschke, J., Reina, J., Llamazares, S., Bertran, T., Rossi, F., Roig, J., Gonzalez, C., 2013. Centrobin controls mother-daughter centriole asymmetry in Drosophila neuroblasts. Nat. Cell Biol. 15, 241248. https://doi.org/10.1038/ncb2671

Kaltschmidt, J.A., Davidson, C.M., Brown, N.H., Brand, A.H., 2000. Rotation and asymmetry of the mitotic spindle direct asymmetric cell division in the developing central nervous system. Nat. Cell Biol. 2, 7-12. https://doi.org/10.1038/71323

Kane, D.A., Kimmel, C.B., 1993. The zebrafish midblastula transition. Development 119, 447-456.

Kondo, T., Hayashi, S., 2013. Mitotic cell rounding accelerates epithelial invagination. Nature 494, 125129. https://doi.org/10.1038/nature11792

Kong, D., Wolf, F., Großhans, J., 2017. Forces directing germ-band extension in Drosophila embryos. Mech. Dev. 144, 11-22. https://doi.org/10.1016/j.mod.2016.12.001

Korotkevich, E., Niwayama, R., Courtois, A., Friese, S., Berger, N., Buchholz, F., Hiiragi, T., 2017. The Apical Domain Is Required and Sufficient for the First Lineage Segregation in the Mouse Embryo. Dev. Cell 40, 235-247.e7. https://doi.org/10.1016/j.devcel.2017.01.006

Kotak, S., Gönczy, P., 2013. Mechanisms of spindle positioning: cortical force generators in the limelight. Curr. Opin. Cell Biol. 25, 741-748. https://doi.org/10.1016/j.ceb.2013.07.008

Kumano, G., Nishida, H., 2007. Ascidian embryonic development: an emerging model system for the study of cell fate specification in chordates. Dev. Dyn. 236, 1732-1747. https://doi.org/10.1002/dvdy.21108

Kumano, G., Takatori, N., Negishi, T., Takada, T., Nishida, H., 2011. A maternal factor unique to ascidians silences the germline via binding to P-TEFb and RNAP II regulation. Curr. Biol. 21, 1308-1313. https://doi.org/10.1016/j.cub.2011.06.050

Kuroda, R., Endo, B., Abe, M., Shimizu, M., 2009. Chiral blastomere arrangement dictates zygotic leftright asymmetry pathway in snails. Nature 462, 790-794. https://doi.org/10.1038/nature08597

Kuroda, R., Fujikura, K., Abe, M., Hosoiri, Y., Asakawa, S., Shimizu, M., Umeda, S., Ichikawa, F., Takahashi, H., 2016. Diaphanous gene mutation affects spiral cleavage and chirality in snails. Sci Rep 6, 34809. https://doi.org/10.1038/srep34809 
Lemaire, P., 2009. Unfolding a chordate developmental program, one cell at a time: invariant cell lineages, short-range inductions and evolutionary plasticity in ascidians. Dev. Biol. 332, 48-60. https://doi.org/10.1016/j.ydbio.2009.05.540

Lydersen, B.K., Pettijohn, D.E., 1980. Human-specific nuclear protein that associates with the polar region of the mitotic apparatus: distribution in a human/hamster hybrid cell. Cell 22, 489-499.

Maître, J.-L., Turlier, H., Illukkumbura, R., Eismann, B., Niwayama, R., Nédélec, F., Hiiragi, T., 2016. Asymmetric division of contractile domains couples cell positioning and fate specification. Nature 536, 344-348. https://doi.org/10.1038/nature18958

McDougall, A., Chenevert, J., Pruliere, G., Costache, V., Hebras, C., Salez, G., Dumollard, R., 2015. Centrosomes and spindles in ascidian embryos and eggs. Methods Cell Biol. 129, 317-339. https://doi.org/10.1016/bs.mcb.2015.03.006

Merdes, A., Ramyar, K., Vechio, J.D., Cleveland, D.W., 1996. A Complex of NuMA and Cytoplasmic Dynein Is Essential for Mitotic Spindle Assembly. Cell 87, 447-458. https://doi.org/10.1016/S00928674(00)81365-3

Minc, N., Burgess, D., Chang, F., 2011. Influence of cell geometry on division-plane positioning. Cell 144, 414-426. https://doi.org/10.1016/j.cell.2011.01.016

Minc, N., Piel, M., 2012. Predicting division plane position and orientation. Trends Cell Biol. 22, 193-200. https://doi.org/10.1016/j.tcb.2012.01.003

Negishi, T., Kumano, G., Nishida, H., 2011. Polo-like kinase 1 is required for localization of Posterior End Mark protein to the centrosome-attracting body and unequal cleavages in ascidian embryos. Dev. Growth Differ. 53, 76-87. https://doi.org/10.1111/j.1440-169X.2010.01231.x

Negishi, T., Takada, T., Kawai, N., Nishida, H., 2007. Localized PEM mRNA and protein are involved in cleavage-plane orientation and unequal cell divisions in ascidians. Curr. Biol. 17, 1014-1025. https://doi.org/10.1016/j.cub.2007.05.047

Nelson, B.H., Weisblat, D.A., 1992. Cytoplasmic and cortical determinants interact to specify ectoderm and mesoderm in the leech embryo. Development 115, 103-115.

Newport, J., Kirschner, M., 1982. A major developmental transition in early Xenopus embryos: I. characterization and timing of cellular changes at the midblastula stage. Cell 30, 675-686.

Nishida, H., 2005. Specification of embryonic axis and mosaic development in ascidians. Dev. Dyn. 233, 1177-1193. https://doi.org/10.1002/dvdy.20469

Nishida, H., 1996. Vegetal egg cytoplasm promotes gastrulation and is responsible for specification of vegetal blastomeres in embryos of the ascidian Halocynthia roretzi. Development 122, 12711279.

Nishida, H., Sawada, K., 2001. macho-1 encodes a localized mRNA in ascidian eggs that specifies muscle fate during embryogenesis. Nature 409, 724-729. https://doi.org/10.1038/35055568

Nishikata, T., Hibino, T., Nishida, H., 1999. The centrosome-attracting body, microtubule system, and posterior egg cytoplasm are involved in positioning of cleavage planes in the ascidian embryo. Dev. Biol. 209, 72-85. https://doi.org/10.1006/dbio.1999.9244

Olivier, N., Luengo-Oroz, M.A., Duloquin, L., Faure, E., Savy, T., Veilleux, I., Solinas, X., Débarre, D., Bourgine, P., Santos, A., Peyriéras, N., Beaurepaire, E., 2010. Cell lineage reconstruction of early zebrafish embryos using label-free nonlinear microscopy. Science 329, 967-971. https://doi.org/10.1126/science.1189428

Parisi, E., Filosa, S., De Petrocellis, B., Monroy, A., 1978. The pattern of cell division in the early development of the sea urchin. Paracentrotus lividus. Dev. Biol. 65, 38-49.

Peng, C.J., Wikramanayake, A.H., 2013. Differential regulation of disheveled in a novel vegetal cortical domain in sea urchin eggs and embryos: implications for the localized activation of canonical Wnt signaling. PLoS ONE 8, e80693. https://doi.org/10.1371/journal.pone.0080693 
Peng, J.C.-F., Wang, L., Wikramanayake, A.H., 2017. Origins of anterior-posterior polarity by localized activation of Disheveled. Mol. Reprod. Dev. 84, 443. https://doi.org/10.1002/mrd.22839

Pierre, A., Sallé, J., Wühr, M., Minc, N., 2016. Generic Theoretical Models to Predict Division Patterns of Cleaving Embryos. Dev. Cell 39, 667-682. https://doi.org/10.1016/j.devcel.2016.11.018

Pietro, F. di, Echard, A., Morin, X., 2016. Regulation of mitotic spindle orientation: an integrated view. EMBO reports 17, 1106-1130. https://doi.org/10.15252/embr.201642292

Prodon, F., Chenevert, J., Hébras, C., Dumollard, R., Faure, E., Gonzalez-Garcia, J., Nishida, H., Sardet, C., McDougall, A., 2010. Dual mechanism controls asymmetric spindle position in ascidian germ cell precursors. Development 137, 2011-2021. https://doi.org/10.1242/dev.047845

Prodon, F., Yamada, L., Shirae-Kurabayashi, M., Nakamura, Y., Sasakura, Y., 2007. Postplasmic/PEM RNAs: a class of localized maternal mRNAs with multiple roles in cell polarity and development in ascidian embryos. Dev. Dyn. 236, 1698-1715. https://doi.org/10.1002/dvdy.21109

Prulière, G., Cosson, J., Chevalier, S., Sardet, C., Chenevert, J., 2011. Atypical protein kinase C controls sea urchin ciliogenesis. Mol. Biol. Cell 22, 2042-2053. https://doi.org/10.1091/mbc.E10-10-0844

Ragkousi, K., Marr, K., McKinney, S., Ellington, L., Gibson, M.C., 2017. Cell-Cycle-Coupled Oscillations in Apical Polarity and Intercellular Contact Maintain Order in Embryonic Epithelia. Curr. Biol. 27, 1381-1386. https://doi.org/10.1016/j.cub.2017.03.064

Redemann, S., Pecreaux, J., Goehring, N.W., Khairy, K., Stelzer, E.H.K., Hyman, A.A., Howard, J., 2010. Membrane invaginations reveal cortical sites that pull on mitotic spindles in one-cell $C$. elegans embryos. PLoS ONE 5, e12301. https://doi.org/10.1371/journal.pone.0012301

Ren, X., Weisblat, D.A., 2006. Asymmetrization of first cleavage by transient disassembly of one spindle pole aster in the leech Helobdella robusta. Dev. Biol. 292, 103-115. https://doi.org/10.1016/j.ydbio.2005.12.049

Robert, A, 1903. Sur le développement des Troches. Thesis. Faculté des Sciences de L'Université de Paris.

Saadaoui, M., Machicoane, M., di Pietro, F., Etoc, F., Echard, A., Morin, X., 2014. Dlg1 controls planar spindle orientation in the neuroepithelium through direct interaction with LGN. J. Cell Biol. 206, 707-717. https://doi.org/10.1083/jcb.201405060

Sachs, J., 1878. Uber die Anordnung der Zellen in jungsten Pflanzentheilen. Arb. Bot. Inst. Wurzburg 2, 46-104.

Sachs, J. von, 1887. Lecture XXVII. Relations between growth and cell-division in the embryonic tissues. lectures in plant physiology. clarendon Press, Oxford 431-459.

Sardet, C., McDougall, A., Houliston, E., 1994. Cytoplasmic domains in eggs. Trends Cell Biol. 4, 166-172.

Savoian, M.S., Rieder, C.L., 2002. Mitosis in primary cultures of Drosophila melanogaster larval neuroblasts. J Cell Sci 115, 3061-3072.

Schaefer, M., Shevchenko, A., Shevchenko, A., Knoblich, J.A., 2000. A protein complex containing Inscuteable and the Galpha-binding protein Pins orients asymmetric cell divisions in Drosophila. Curr. Biol. 10, 353-362.

Schroeder, T.E., 1980. Expressions of the prefertilization polar axis in sea urchin eggs. Dev. Biol. 79, 428443.

Shibazaki, Y., Shimizu, M., Kuroda, R., 2004. Body handedness is directed by genetically determined cytoskeletal dynamics in the early embryo. Curr. Biol. 14, 1462-1467. https://doi.org/10.1016/j.cub.2004.08.018

Shimizu, T., Ishii, R., Takahashi, H., 1998. Unequal cleavage in the early Tubifex embryo. Dev. Growth Differ. 40, 257-266.

Siller, K.H., Cabernard, C., Doe, C.Q., 2006. The NuMA-related Mud protein binds Pins and regulates spindle orientation in Drosophila neuroblasts. Nat. Cell Biol. 8, 594-600.

https://doi.org/10.1038/ncb1412 
Siller, K.H., Doe, C.Q., 2009. Spindle orientation during asymmetric cell division. Nat. Cell Biol. 11, 365374. https://doi.org/10.1038/ncb0409-365

Siller, K.H., Doe, C.Q., 2008. Lis1/dynactin regulates metaphase spindle orientation in Drosophila neuroblasts. Dev. Biol. 319, 1-9. https://doi.org/10.1016/j.ydbio.2008.03.018

Sobral, D., Tassy, O., Lemaire, P., 2009. Highly Divergent Gene Expression Programs Can Lead to Similar Chordate Larval Body Plans. Current Biology 19, 2014-2019. https://doi.org/10.1016/j.cub.2009.10.036

Stolfi, A., Lowe, E.K., Racioppi, C., Ristoratore, F., Brown, C.T., Swalla, B.J., Christiaen, L., 2014. Divergent mechanisms regulate conserved cardiopharyngeal development and gene expression in distantly related ascidians. Elife 3. https://doi.org/10.7554/eLife.03728

Takatori, N., Kumano, G., Saiga, H., Nishida, H., 2010. Segregation of germ layer fates by nuclear migration-dependent localization of Not mRNA. Dev. Cell 19, 589-598. https://doi.org/10.1016/j.devcel.2010.09.003

Tassy, O., Daian, F., Hudson, C., Bertrand, V., Lemaire, P., 2006. A quantitative approach to the study of cell shapes and interactions during early chordate embryogenesis. Curr. Biol. 16, 345-358. https://doi.org/10.1016/j.cub.2005.12.044

Théry, M., Jiménez-Dalmaroni, A., Racine, V., Bornens, M., Jülicher, F., 2007. Experimental and theoretical study of mitotic spindle orientation. Nature 447, 493-496. https://doi.org/10.1038/nature05786

Thompson, D.W., 1942. On growth and form, new ed. Cambridge, and New York: Cambridge University Press, and Macmillan Company.

Treen, N., Heist, T., Wang, W., Levine, M., 2018. Depletion of Maternal Cyclin B3 Contributes to Zygotic Genome Activation in the Ciona Embryo. Curr. Biol. 28, 1330-1331. https://doi.org/10.1016/j.cub.2018.03.058

Turlier, H., Maître, J.-L., 2015. Mechanics of tissue compaction. Semin. Cell Dev. Biol. 47-48, 110-117. https://doi.org/10.1016/j.semcdb.2015.08.001

Voronina, E., Wessel, G.M., 2006. Activator of G-protein signaling in asymmetric cell divisions of the sea urchin embryo. Dev. Growth Differ. 48, 549-557. https://doi.org/10.1111/j.1440169X.2006.00895.X

Weitzel, H.E., Illies, M.R., Byrum, C.A., Xu, R., Wikramanayake, A.H., Ettensohn, C.A., 2004. Differential stability of beta-catenin along the animal-vegetal axis of the sea urchin embryo mediated by dishevelled. Development 131, 2947-2956. https://doi.org/10.1242/dev.01152

Wieschaus, E., Nüsslein-Volhard, C., 2016. The Heidelberg Screen for Pattern Mutants of Drosophila: A Personal Account. Annu. Rev. Cell Dev. Biol. 32, 1-46. https://doi.org/10.1146/annurev-cellbio113015-023138

Wieschaus, E., Nüsslein-Volhard, C., 2014. Walter Gehring (1939-2014). Current Biology 24, R632-R634. https://doi.org/10.1016/j.cub.2014.06.039

Wilson, E. B, 1896, 1905, 1915. The cell in development and inheritance. London Macmillan and Co.

Winklbauer, R., 2015. Cell adhesion strength from cortical tension - an integration of concepts. J. Cell. Sci. 128, 3687-3693. https://doi.org/10.1242/jcs.174623

Woolner, S., Papalopulu, N., 2012. Spindle position in symmetric cell divisions during epiboly is controlled by opposing and dynamic apicobasal forces. Dev. Cell 22, 775-787. https://doi.org/10.1016/j.devcel.2012.01.002

Xiong, F., Ma, W., Hiscock, T.W., Mosaliganti, K.R., Tentner, A.R., Brakke, K.A., Rannou, N., Gelas, A., Souhait, L., Swinburne, I.A., Obholzer, N.D., Megason, S.G., 2014. Interplay of cell shape and division orientation promotes robust morphogenesis of developing epithelia. Cell 159, 415-427. https://doi.org/10.1016/j.cell.2014.09.007 
Yamamoto, K., Kimura, A., 2017. An asymmetric attraction model for the diversity and robustness of cell arrangement in nematodes. Development 144, 4437-4449. https://doi.org/10.1242/dev.154609

Yu, F., Morin, X., Cai, Y., Yang, X., Chia, W., 2000. Analysis of partner of inscuteable, a novel player of

Drosophila asymmetric divisions, reveals two distinct steps in inscuteable apical localization. Cell 100, 399-409. 